\title{
HERNAN MALO Y LA CULTURA
}

\author{
Edmundo Ribadeneira
}


Durante muchos años de vida universitaria, compartí con Hernán Malo González los problemas propios de la Universidad ecuatoriana y, concretamente, los que afectaban a la Pontificia Universidad Católica y a la Central del Ecuador.

Fue, sin duda, una excelente oportunidad para conocer a un hombre valioso, entrañablemente humano, gentil y talentoso como pocos. Un gran honor fue para mí y desde luego sumamente grato, llegar a considerar a Hernán Malo como uno de mis mejores amigos, entre los más queridos y respetados.

Ciertamente, buena y larga era la madera humana de quien, en la dirección de una importante universidad nacional, en el ejercicio de la docencia, en la actividad intelectual y otras funciones motivadoras del arte y la literatura, de la investigación académica y el pensamiento filosófico, cumplió una labor extraordinaria, desgraciadamente frustrada en una hora que el poeta Neruda no hubiera vacilado en llamar de perros y de ratas.

Duele hondamente esta irreparable pérdida, en los precisos momentos en que avanzaba admirablemente la publicación de una serie de libros destinados a conformar una imagen intelectual completa y auténtica de nuestro país.

Por supuesto, y no puede ser de otro modo, esta gran obra continuará realizándose, fue proyectada por Hernán Malo González, cuyo recuerdo será permanente como son los libros mismos.

Y en esto de establecer una progenie cultural y un discipulado tan fervoroso como el propio maestro, hemos de ver la fuerza de un espíritu transferida a las personas en cuyas manos y bajo cuya responsabilidad ha quedado la colección de publicaciones que se amparan en la Corporación Editora Nacional.

Pero junto a las cosas grandes a través de cuya presencia el hombre puede inmortalizarse, están las otras, más en la médula o la esencia fundamental del hombre. 
Evocaré de Hernán su limpia sonrisa, su fino sentido del humor, signo de vitalidad y fuerza; esa estremecida ternura mediante la cual reaccionaba con asombro y a veces con tristeza, con júbilo y también con cierta forma de retenida ira.

Era, en suma, un ser humano burilado por los cuatro costados: de ideas firmes que sostenía apoyado por una lúcida euforia; honesto en el manejo diario de su propia conciencia; inteligente en el marco de una extremada sencillez, a la manera del agua, que mientras menos sabor tiene, más pura es; activo en función de una pasión ecuatoriana que le movió a organizar aquella colección bibliográfica, que debería recibir su nombre.

Cuántas veces fuimos juntos de un lado hacia otro, en misión universitaria casi siempre difícil y dura. Y cómo supimos afrontar los problemas, en mi caso gracias a la facilidad con que Hernán podía transmitir su capacidad de equilibrio y honda serenidad.

Recordaré siempre nuestra discusión trascendente, cuando en la ciudad de Moscú pugnamos por identificar a Dios con las ciudades hermosas, como París, o feas como algunas del mundo socialista. Si Dios, en definitiva, idea o realidad, estaba más allegado a la estética o más consustanciado con la ética.

Dolorosa pérdida para la cultura y el pueblo, este viaje repentino de Hernán al reino del silencio: precipitada y malhadada ausencia que nos molestará siempre como una espina de hielo clavada en el corazón.

Pero su memoria estará siempre erguida como una bandera de afecto y virtudes estelares. Nos acompañará como un amigo leal y pulcro. $\mathrm{Y}$ tendremos que acostumbrarnos a su evocación permanentemente, porque su obra tiene que proseguir y de esta manera él se quedará con nosotros definitivamente. 